\title{
Structure of Karonese Conversation in the Funeral: Case Study in Indonesia
}

\author{
Siti Aisah Ginting ${ }^{1}$ \\ ${ }^{1}$ Faculty of Languages and Arts Universitas Negeri Medan, Indonesia \\ Correspondence: Siti Aisah Ginting, English and Literature Department, Faculty of Languages and Arts, \\ Universitas Negeri Medan, Jl. Willem Iskandar Pasar V - Kotak Pos No. 1589 - Medan 20221, Indonesia. E-mail: \\ aisah_ginting@yahoo.co.id
}

Received: January 19, 2015 Accepted: April 4, 2015 Online Published: May 16, 2015

doi:10.5539/ass.v11n13p298 URL: http://dx.doi.org/10.5539/ass.v11n13p298

\begin{abstract}
The objective of this article is to inform and formulate the structure of Karonese conversation on the funeral. These data of research were collected by recording the conversation in Karonese funeral and were analyzed based on the Systemic Functional Linguistics theory. Based on the result of research, it was found that the occurring conversation was caused by the influence of Karonese culture in which the speaker could interact by projecting him/herself as the dead person. Therefore, there were three kinds of conversation structures; they were the conversation structure occurring universally, the conversation structure of development, which was the development from universal conversation structure and unusual conversation structure, which was the conversation structure that was not same with universal conversation structure.
\end{abstract}

Keywords: conversation system, conversation structure, funeral, and networking conversation

\section{Introduction}

Death, birth, and marriage are sacred things for Karonese ethnic. The importance of the three elements for Karonese ethnic is signed by various ceremonies when they happen. In marriage, for instance, it is done in three steps i.e. Nungkuni 'asking', Embah belo selambar 'proposing', nganting manok 'engagement', and pedalan ulu emas 'marrying' (Ginting, 2010). Those three steps have equally important meaning for Karonese people. Therefore, the three are done consequently. So is the birth. The presence of new family member is meaningful because it is regarded as the generation development; moreover, it will be more meaningful if the new member is male since son is the one inheriting the line of descent. Thus, before the new member is born, the welcoming or praying ceremony has been done when the baby is seven-month-age in the mother's womb. Then, after the baby was born, a ceremony called by turun ku lau is conducted.

If the presence of family member is important thing, the death is more important thing for Karonese ethnic. Somebody's death will be very meaningful for the family being left if all his or her children already have their own family. That condition is called as cawir metua. Therefore, if somebody dies in cawir metua condition, his or her children will hold funeral following the customs in Karonese culture. The tradition held after letting the cawir metua go is giving a memento in the form of clothes and money which belong to the dead person to the family being left. Giving the memento is started with a speech from the nuclear family and sangkep geluh (Ginting, 2010). The speech given by the nuclear family and sangkep geluh is not only for the family being left but also for the late one. The speaker speaks to the dead person by projecting him/herself as the dead person so that there is an unusual move. It is said an unusual because usually the speaker interacts with human, not dead person. Therefore, there is a move happened in the context of death in Karonese ethnic.

\section{Metafunction of Language}

In Systemic Functional Linguistics (SFL), metafunction of language is known consisting of 'ideational function' (to represent), 'interpersonal function' (to exchange), and 'textual function' (to organize experience). Ideational function is divided into two parts which are 'experiential function' as language function to describe the experience and 'logical function' as language function to relate the experiences. The experimental function is language function to describe human's experiences. The language user presents his/her non-linguistic experiences about the universe into semiotic-linguistic experiences because only the semiotic-linguistic presence 
can be exchanged with addressee as interlocutor in social context communication. Somebody's experiences about something whether it is events, situations or conditions are different. The speaker can present those differences through language use.

Besides presenting the experiences, the speaker exchanges linguistic experiences with listener to fulfill the needs called as 'interpersonal meaning'. Then, the language user organizes the experiences in which there is relationship in the organization: one unit experience in 'ideational meaning' and 'interpersonal meaning' is relevant with the existing experience and has been and will be delivered before and after it which is called as 'textual function' (Halliday, 1978; Matthiesen, 1995).

The four functions used by speaker in exchanging the experiences are question, statement, command and offer. These four are realized in the form of mood, modality, epithet, exchange structure, which builds conversational structure. According to Young and Fitzgerald (2006), when someone exchanges information, he/she expresses his/her attitude and commitment into discourse including conversation topic and interlocutor. These attitude and commitment are presented through modality and adverb. By using modality and adverb, the speaker can add element modifying proposition and changing proposition into statement, which is signed by opinions, belief, and view. For instance, a speaker said "Father goes to Jakarta tomorrow". This clause may contain personal content so that it can be changed to "father will go to tomorrow", "father must go to tomorrow", and "father may go tomorrow". The use of modality "must, will, and may" is called as personal consideration. When the exchange happens, the speaker and the interlocutor are categorized as different speaker roles through mode use whether it is giving information or asking information.

The third language function is textual function, which is language function to organize the experiences. The speaker organized his/her experiences in order; for example, what the speaker wants to present it first and it is followed by others can be done by using language. Language element, which is presented, first is called as 'Theme' and what is followed is known as 'Rheme'. For instance, 'The students listen carefully to the lecture delivered by the lecturer'. 'Carefully, the students listen to the lecture delivered by the lecturer'. In 'The students listen carefully to the lecture delivered by the lecturer', element in front is 'student'; meanwhile, in 'Carefully, the students listen to the lecture delivered by the lecturer', element in front in how students listen to the lecture delivered by the lecturer.

Related to language metafunction in funeral in Karonese ethnic, language functions taken place are not only language function as presenting experiences but also language function as exchanging experiences. The speaker exchanges the experiences with the dead people by projecting him/herself as the dead person.

\subsection{Social Context}

Interaction of alive person with dead person like above is a culture in Karonese ethnic. The culture will influence the use of language because based on Systemic Functional Linguistics, language is semiotic social. Language is not only seen as the meaning but also regarded as the provided system so that culture, history, and political dimension are counted in analyzing the meaning (Halliday, 1978; Lemke, 1985). Related to the happening discourse in Karonese funeral, Karonese culture is counted in analysis since the speaker of Karonese language in using language is influenced by factors from inside and outside of that language. The factors from outside of language are called as social context. Then, Halliday and Martin (1993, p. 24) assert that there is relationship between language and social context. This relationship is dynamic and is called as two-ways relationship i.e. language is something presenting information and presented by its social context. Therefore, based on the context, the language used can be predicted and based on the language used; the context where the interaction happened can be known.

Social context consists of three strata; in order from the most abstract to the most concrete, it includes ideology, culture, and context of situation (Martin, 1992; Halliday, 1985). Then, social context is divided into three; they are context of situation, context of culture and context of ideology. Context of situation consists of (1) field or what is spoken, (2) tenor or who is speaking, and (3) mode or how the conversation is done i.e. oral or written (Halliday \& Hasan, 1985). Field is what is spoken referring to the event, social activity, and character of speaker, interlocutor, and meaning domain. In other words, field is how participants are involved in it and how language is realized as essential component (Halliday, 1985, p. 12). Martin (1992, p. 292) defines field as a tool of activities in sequence, which is oriented on global institutional purpose. Tenor is describing relationship between speaker and interlocutor, and also the speaking roles, which are done by speaker and interlocutor called as social relationship where they are involved (Halliday, 1985, p. 12). Other aspects related to tenor are formality, status or power, and affection. The third component of context is mode, which is how language is used by participants in certain situation including media or facility used in communication. The components included in mode are 
planning, distance, media or network. Halliday adds that in mode context, the purpose of discourse is also included as what is gained from text which is realized whether it is persuasion, exposition, or others.

Furthermore, the relationship of mode and language metafunction can be developed into experiential meaning and interpersonal meaning. Experiential meaning puts semiotic space to center of language as part of action and language as reflection. Moreover, interpersonal meaning puts the space to center of monolog and dialog, visual character, oral contact and feedback that may happen among participants (Martin, 1992).

Social context is limited as gradual social activities to achieve a goal (Martin, 1986). The context of culture includes three thing; they are (1) possibility limitation of the three components of situation context, (2) stages that must be passed in one social interaction, and (3) the purpose that will be achieved in social interaction. Each social interaction has certain purpose that is called as function of text.

Ideological context refers to the social construction or concept determining what is supposed or not supposed to do by somebody in a social interaction. Context of ideology includes value, views, and perspective (Eggin, 1994), which are approved by society in one community. In other words, ideology is ideal concept or image wanted by society members in a community consisting what is wanted and what is unwanted to happen. The three components of this context accompany the language gradually and build semiotic graded relationship with language text. The relation from the lowest level of phonology to the highest level of ideology can be drawn as Figure 1.

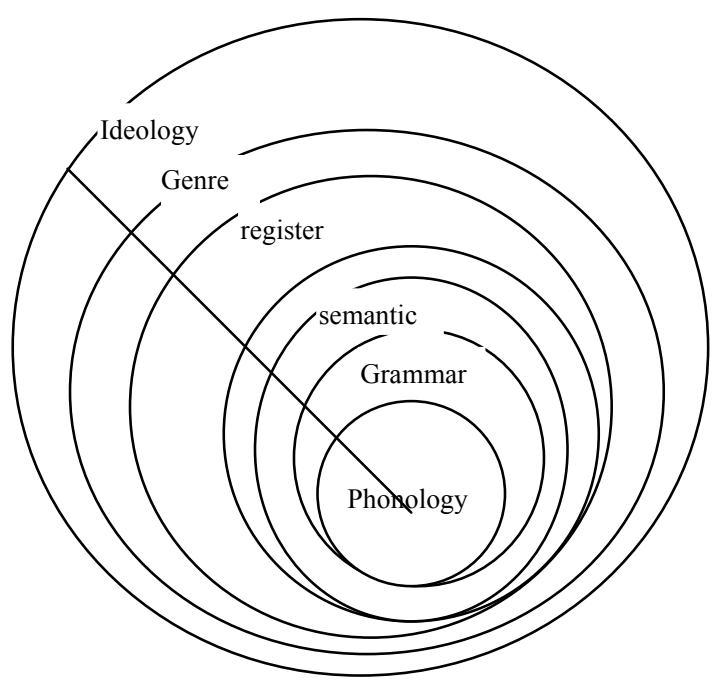

Figure 1. Language and its semiotic environment

Figure 1 show that the most concrete context is because context of situation/ register is directly connected to text or language, which are semantics, grammar, and phonology as language components. Furthermore, the next is context of culture and the most abstract is context of ideology since both contexts are realized through language.

Related to this writing, which is system and structure of conversation in Karonese funeral, context of culture influence conversation system; there are interaction between speaker and the dead person by projecting the speaker him/herself as the dead person. Besides context of culture, context of situation also influences conversation system in Karonese language. The intended context of situation is the activities, which are usually done by Karonese speaker, in this case in funeral.

\subsection{System of Conversation}

In Systemic Functional Linguistics, system is choices presented with network system that show certain characteristics. If a characteristic is not fulfilled, the choice will be done. Since the system is choices, system is regarded as paradigmatic. Different with system, structure is sequences of horizontal components and it is syntagmatic. According to Hjelmslev (1961) in Martin (1992, p. 4), paradigmatic relationship is mapped in potential (hidden) form; meanwhile, syntagmatic is real form. In other words, structure is realization of underlain system. All aspects of language and social context are described based on system and structure.

Matthiessen (1992, p. 632) categorizes system into two, which are algebraic way and graphic way. In algebraic way, ' $x$ : $a / b$ ' means that ' $x$ ' is presented by features ' $a$ ' and ' $b$ '. In detail, that system can be read as if there is ' $x$ ', 
the existing choice will be whether a feature ' $a$ ' or a feature ' $b$ ' is the choice. Meanwhile, the second category is the use of graph, which simply can be seen in Graph 1 as follows.

$1 . x \rightarrow\left[\begin{array}{l}a \\ b\end{array}\right.$

This notation suuws ura aspect ' $x$ ' consists of ' $a$ ' and ' $b$ '. If ' $x$ ' is chosen, then ' $x$ ' will be ' $a$ ' or ' $b$ '. In the use of language, the more concrete example is a 'sentence', which can be presented in choice 'positive' or 'negative'. In algebraic way, this system will be read as 'sentence: positive/negative'. This system equivalence can be seen in Graph 2 in the following:

$$
\text { Positif }
$$

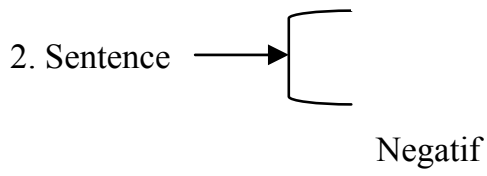

It is easily understood that sentence can consists of positive or negative sentence. These two representations can be continuously developed when the availability of choices is more and more specific based on the context. That system can widen; for example if ' $\mathrm{P}$ ', so ' $\mathrm{x} / \mathrm{y}$ '; if ' $\mathrm{x}$ ', so ' $\mathrm{a} / \mathrm{b}$ '; if ' $\mathrm{y}$ ', so ' $\mathrm{c} / \mathrm{d}$ '. Moreover, this form is equivalent with Graph 3 in the following.

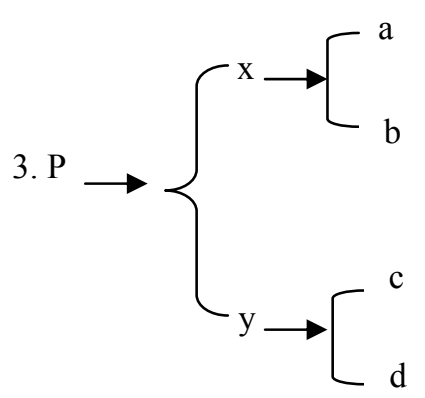

More broadly, it can be explained from that graph that aspect ' $P$ ' consists of 2 components ' $x$ ' and ' $y$ '. Then, ' $x$ ' consists of 'a' and ' $b$ ' and ' $y$ ' consists of 'c' and 'd'. Every choice of one final aspect in one component must be followed by final chosen aspect from other components. That system must produce 4 choices, 'ac', 'ad', 'bc', and 'bd'.

In the use of language, the very concrete example can be taken like it is described in Graph 4 in the following.

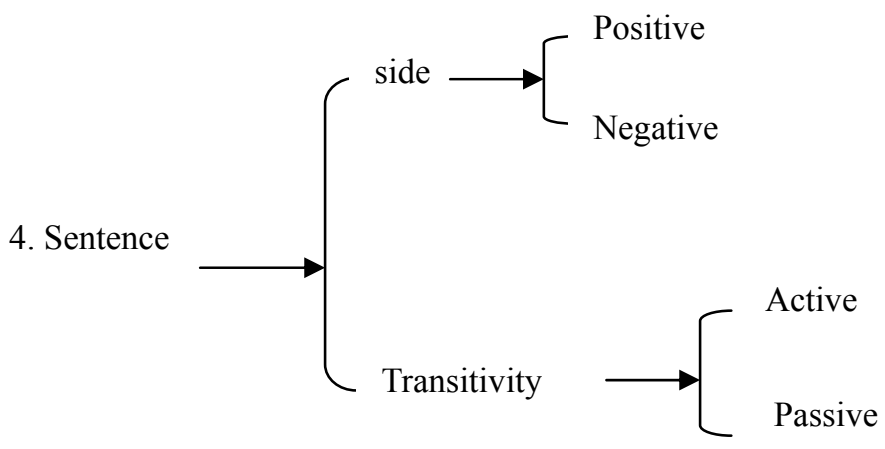

From this graph, there are four choices of sentences; they are:

- [Positive/Active]: He catches tiger.

- [Positive/Passive]: He is caught by tiger.

- [Negative/Active]: He does not catch tiger.

- [Negative/Passive]: He is not caught by tiger. 
The following is the further development on the possibility of system formation represented by one of the two forms above. Then, specifically from linguistic elements, there are examples with final goal to ease this study.

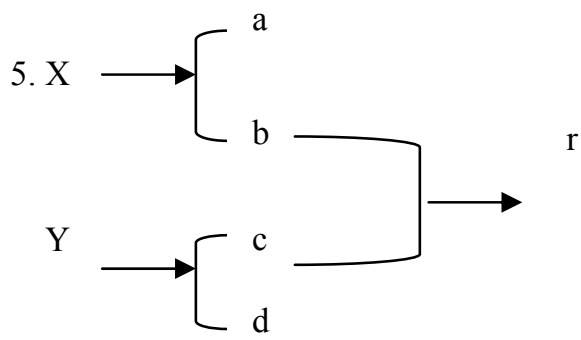

Graph 5 shows a system stating two components become one which is that ' $b$ ' and 'c' produce ' $r$ '. The example in language can be seen in Graph 6 and Graph 7 like as follows:
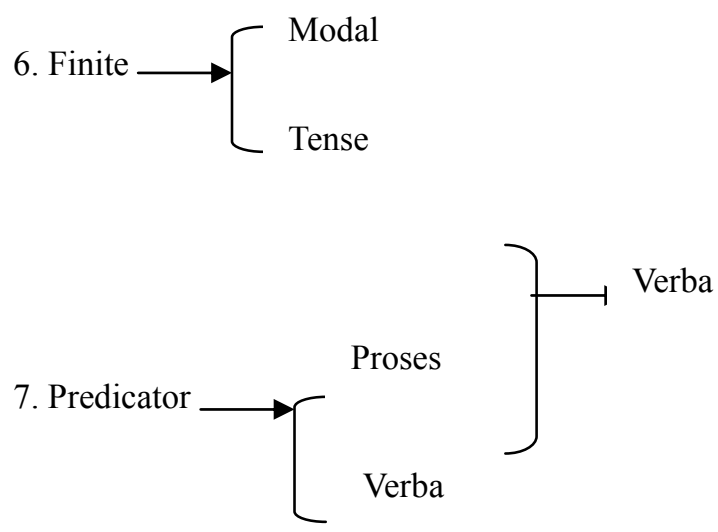

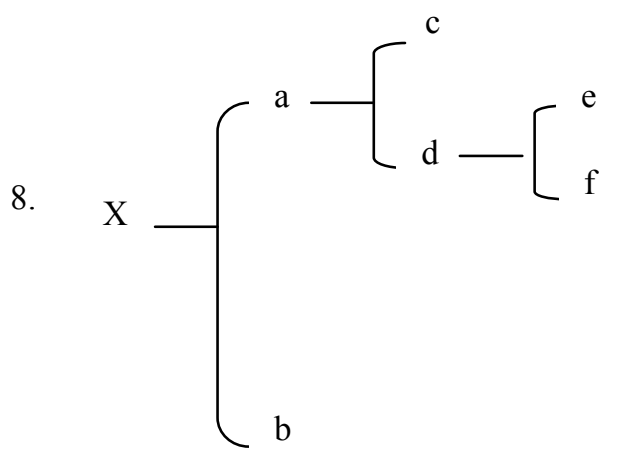

The system seen in Graph 8 shows that if the choice is ' $a$ ' so it is followed by ' $c / d$ ', and if ' $d$ ' is chosen, then ' $e / f$ ' appears. This kind of system can be seen in using language in Graph 9 below:

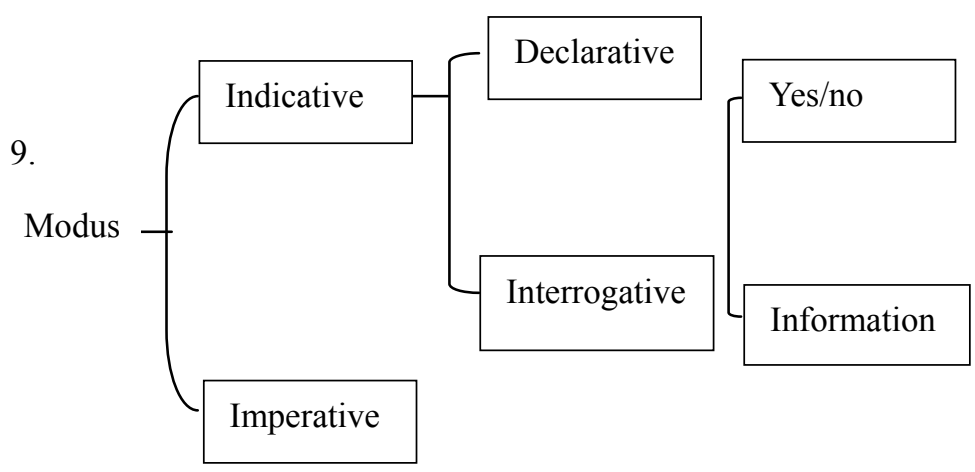

Graph 9 above shows that there are choices coming from mode (resource to negotiate the meaning in 
conversation), which is whether the choice is indicative or imperative. If indicative is chosen, the choice must be whether it is declarative or interrogative. Also, if interrogative is chosen, the other choice is whether interrogative in the form of yes/no question clause or question clause. Therefore, the choice always appears and is not the only one; it shows that network system is presented in language as a resource, not a rules tool (Martin, 1992, p. 5).

As being known, the language use is never separated from social context. The use of elements of language as explained before crucially depends on social context happened in communication. Therefore, the choices of language elements like declarative, imperative, and other sentences by speaker and interlocutor are always based on the social context.

To ease how the choice is chosen by speaker based on context of situation, the following is the explanation on position of the choice/system in the context of situation.

Various arguments about context of situation have been formulated by the linguists such as Poynton; Thomas, et al (2000); Fowler, Hodge, Kress (2001); Romaine (2000), Holmes (2001); Stockwell (2002) and Fitsgerald (2006) which are different one to another. Nevertheless, those differences do not contradict one to another. Their arguments can be formulated into one system described in Figure 2.

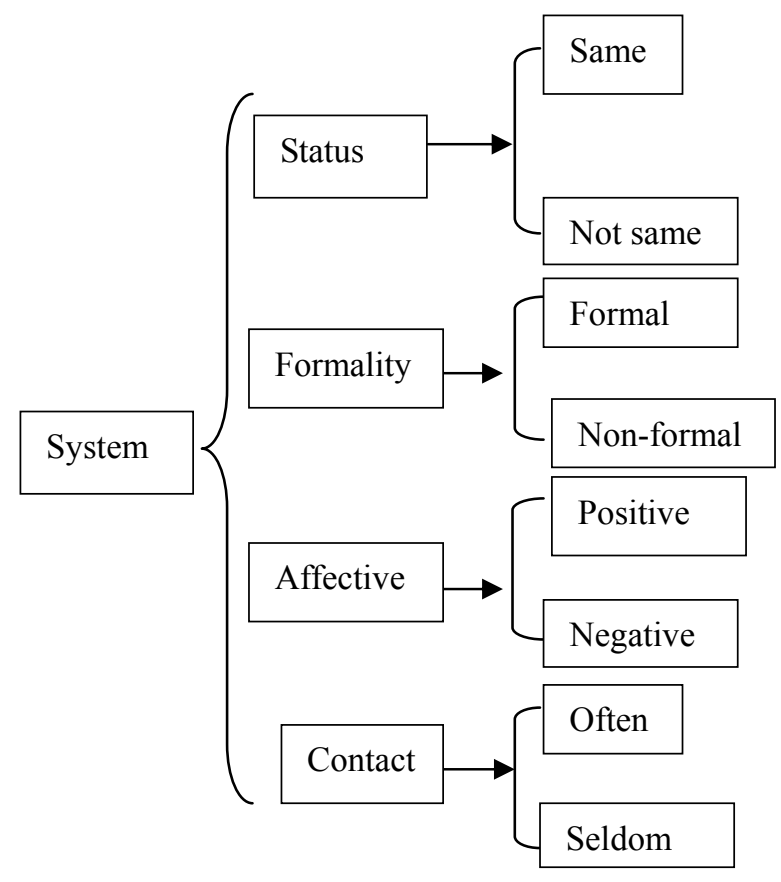

Figure 2. Conversation system according situation context

Figure 2 shows that in context of situation, there are elements that need to be observed in communication; they are status, formality, affective, and contact. The status is differentiated by equal or unequal; formality is situation and condition of conversation which is classified into formal or informal; affective is conversation condition whether it is positive or negative; and contact is frequently or infrequently the conversation happens. The system of social context also shows that the speaker in communication will observe who the interlocutor is based on the four components above. Somebody's status indicates that he/she has power. His/her power may force someone to do something as he/she wants (Thomas et al., 2000). The existence of speaker's status and power is caused by some factors such as wealth, ethnic, social position, age, geographical condition, sex, knowledge, and physical appearance (Fowler, Hodge, \& Kress, 2001). Meanwhile, according to Romaine (2000), Holmes (2001), and Stockwell (2002), the existence of status and power is caused by age, sex, ethnic, gender, social network, official position, and social class. Then, besides factors mentioned above, Fitsgerald (2006), Thomas, et al (2000) also add racism and politics as the cause of the existence of status and power. A speaker who has younger age will use this question sentence "Do you mind lifting that chair?" as replacement of command "Lift that chair!" Besides status, the speaker in exchanging his/her experiences also has to notice the context of conversation happened whether in usual or unusual social context. Usual social context is conversation situation happened in daily life, and unusual social context is social activities related to culture and religion. In exchanging experiences, the 
speaker and the interlocutor also can make the choice directly or indirectly which is the speaker faces the interlocutor directly or use communication tools.

Based on the choices that can be made by speaker and interlocutor, it can be interpreted that in exchanging experiences or in communication, a network system happens in which the speaker and interlocutor can make choices as described in the following figure. Figure 3 shows that conversation system generally consists of three factors, which are event, orientation, and interaction. The event as the first factor has three elements, which are speaker, contact, and context. The speakers usually consist of two or more people who can directly speak one to another. Contact as the second element of event is communication condition happened whether it is face to face or using communication tool. Context is situation happened in conversation whether it is in formal or informal situation, usual or unusual situation.

Orientation as second factor in conversation system shows whether the speaker starts or responds the conversation. The third factor from conversation system is interaction. If there is a response, interaction will happen and conversation is continued based on speaker's needs. If there is no response, there will be no interaction happened. Based on the choices above, the speaker exchanges his/her experience that will build conversational structure.

\subsection{Structure of Conversation}

Structure is realization of system which is horizontal and sequence. If a choice is taken from the system, that choice is represented by structure like the following example in which the chosen is 'respect' sourced from unequal position of 'status' choice side.

Structure: + respect k2: Sir, may I go home?

$$
+ \text { positive } \mathrm{k} 1 \text { : Yes. }
$$

This conversation structure will be clearer if what are meant with negotiation, speech function, and mode are explained first since they are important elements in discourse.

\subsection{Negotiation}

Negotiation is conversation structure in move Martin (1992, p. 31). In relevant thing, Martin and Rose (2002, p. 219) argue that negotiation relates to interaction in a move exchange among the speakers which is how the speakers adopt and sign their own roles in conversation and how moves are arranged related one to another. Move can be defined as function or role-played by addresser in a conversation relating to function or role played by addressee and exchanged commodity (Saragih, 2006, p. 14). Meanwhile, according to Martin (1992), move is valuable leaving point. Then, there are three parameter that can be drawn from that definition and needs to be considered in conversation; they are what will be negotiated, what role is carried out, starting conversation or responding conversation, and whether giving or asking information or giving or asking goods or service (Martin \& Rose, 2002, p. 222).

\subsection{Speech Function and Mode}

Halliday (1994:69) classifies speech function into four groups, which are offer, command, statement, and question. The four are fitted to expected responses, which are 'accepting an offer', 'carrying out command', 'acknowledging a statement', and 'answering a question'. The fundamental purpose in negotiation is giving and accepting or asking and given certain commodity (Thompson, 1996, p. 39). The exchanged commodity is divided into two; they are information and goods \& services. What are included into information is statement and question; meanwhile, offer and command are included into goods and service. The four speech functions are also called as basic speech functions because they can be derived from other speech function and produce eight speech acts, which form the heart of semantic discourse system.

When speaking, the speaker can choose whether it is orientation or negotiation. If orientation is chosen, there will be two choices: greeting or calling. If negotiation, the two choices are either negotiating information or negotiating goods and service. In negotiating information, there are also choices of asking or giving. So is in negotiating goods and service, the two choices are offer or command.

Mode has distinctive structure; essentially it consists of two components, which are Subject component and Finite component. Mode has special role because semantic discourse is realized in that mode. Eggins (1994, p. 153) concludes speech function and mode clause usually used in conversation are: Speech function of Statement - declarative mode, Question - interrogative mode, Command - imperative mode, Offer - modulated interrogative mode, answer - declarative elliptical mode, confession - declarative elliptical mode, receiving - minor clause, and agreement - minor clause. Thompson (1996, p. 40) mentions that three of four speech functions closely relate to 
certain grammatical structure. The statement is often spoken through declarative clause, question through interrogative clause, and command through imperative clause. The strange thing is offer because there is no certain mode choice; however, the offer more relates to modality. Therefore, to analyze the conversation, the differences of each that speech functions have to be known. For instance, speech function of command is usually realized by imperative mode, but it also can be realized in different grammatical forms, which are declarative and interrogative, and so is speech function of question. In English, the question is generally realized by using WH-question, but asking someone's name can be done by using WH-question and using question polarity. Using polarity gives choices to declining the question. In different position or status, incomplete imperative or declarative modes can be used to ask somebody's name.

In conversation, at least there is one move played by speaking in transacting commodity in the form of information, goods, and service. Commodity of information is signed by ' $\mathrm{k}$ ' and commodity of goods and services is signed by ' $a$ '. The conversation is analyzed based on the commodity and speaker role. The role played by the speaker is categorized by 1 and 2 which each is called primary and secondary. The person owning something is the one having primary role signed by 1 . Then, the person asking something is the one having secondary role signed by 2 . If the conversation is continued, it will be signed by ' $\mathrm{f}$ ' (follow up). Therefore, the speaker who has information commodity is signed by $\mathrm{k} 1$ and speaker-asking information is signed by $\mathrm{k} 2$. Then, the speaker having goods and services is signed by a1 and the speaker asking goods and services is signed by a2. If the conversation is continued, $\mathrm{k} 1$ and $\mathrm{k} 2$ become $\mathrm{k} 1 \mathrm{f}$ and $\mathrm{k} 2 \mathrm{f}$, a1 and a2 become a1f and a2f. Different moves of different speakers are related by straight line like examples below which moves $\mathrm{k} 2$ and $\mathrm{k} 2$ are related by straight line. The same moves of same speakers and dynamic moves are related by curved arrow.

$$
\begin{aligned}
& \text { k2: A: Uga nina nande ndu 'What did you mother say?' } \\
& \text { k1: B: Lakai pe 'nothing' }
\end{aligned}
$$

In this conversation, A is coded as $\mathrm{k} 2$ 'secondary knower move' because he/she asks information. B is the source of information that is coded as $\mathrm{k} 1$ 'primary knower move'. $\mathrm{K} 2$ move is used because A does not know or have the information. He/she then knows the information after B told him/her. So, B is the one who firstly knows the information. Therefore, $\mathrm{A}$ is coded as $\mathrm{k} 2$ and $\mathrm{B}$ as $\mathrm{k} 1$. However, that conversation may be continued as follows:

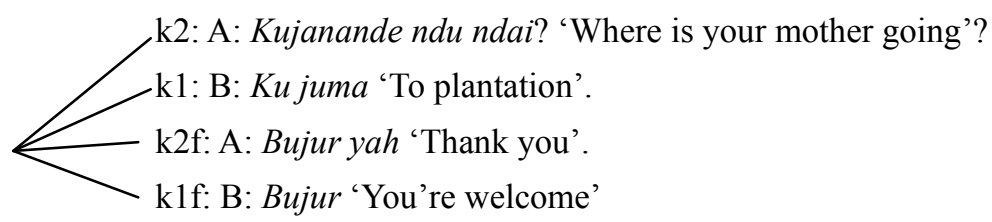

A's follow-up action to B's answer are coded as k2f 'secondary knower's follow-up' and B's follow-up action is coded as k1f 'primary knower's follow-up'. Thus, structure of conversation is formulated as $\mathbf{k} \mathbf{2}^{\wedge} \mathbf{k} \mathbf{1}^{\wedge}(\mathbf{k} \mathbf{2} \mathbf{f})^{\wedge}(\mathbf{k 1 f})$ which means $k 2 f$ and $k 1 f$ may and may not appear.

In other situation, A has known the answer bur he/she pretends that he/she does not know it yet to $\mathrm{B}$. This conversation structure is $\mathbf{d k} \mathbf{1}^{\wedge} \mathbf{k} \mathbf{2}^{\wedge} / \mathbf{k} \mathbf{1} /$. A is coded as dk1 'delayed primary knower' which means that questioner actually has known the answer. So is the interaction with purpose to give or ask goods and services, the structure can be formulated like before with different codes with asking and giving information.

\section{Example:}

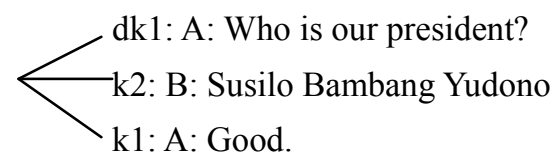

Example:

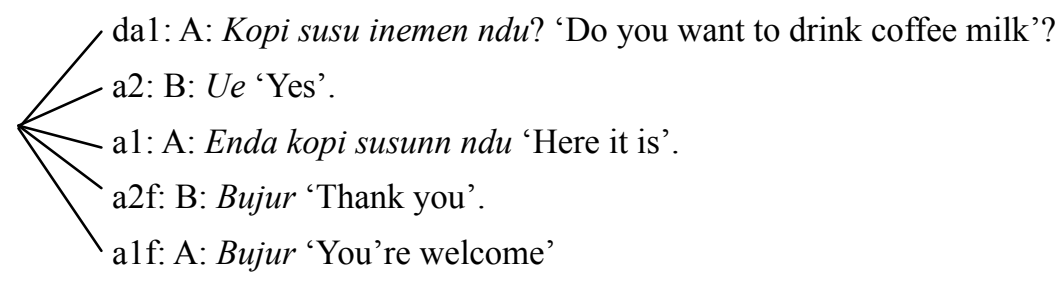

That conversation structure can be formulated as $\mathbf{d a 1} 1^{\wedge} \mathbf{a} 2^{\wedge} \mathbf{a} 1^{\wedge}(\mathbf{a} 2 f)^{\wedge}(\mathbf{a 1 f}) . \mathrm{dA1}$ represents the person delaying giving goods and services 'delayed primary actor', a2 is the person asking goods and services 'secondary actor', 
a1 is the person giving goods and services 'primary actor', a2f is move of follow-up action of the person asking goods and services, and alf is move of follow-up action of the person giving goods and services.

According to Martin (1992), conversation structure both giving and asking information and giving and asking services can be formulated as follows.

1) Giving and asking information: $(\mathbf{d k 1})^{\wedge}(\mathbf{k} 2)^{\wedge} \mathbf{k} 1^{\wedge}(\mathbf{k} \mathbf{2 f})^{\wedge}(\mathbf{k} 1 \mathbf{f})$ and from this formula, there are nine conversation structures that can be derived i.e. $k 1, k 1^{\wedge} k 2 f, k 1^{\wedge} k 2 f^{\wedge} k 1 f, k 2^{\wedge} k 1, k 2^{\wedge} k 1^{\wedge} k 2 f, k 2^{\wedge} k 1^{\wedge} k 2 f^{\wedge} k 1 f$, $\mathrm{dk} 1^{\wedge} \mathrm{k} 2^{\wedge} \mathrm{k} 1$, dk $1^{\wedge} \mathrm{k} 2^{\wedge} \mathrm{k} 1^{\wedge} \mathrm{k} 2 \mathrm{f}$, and $\mathrm{dk} 1^{\wedge} \mathrm{k} 2^{\wedge} \mathrm{k} 1^{\wedge} \mathrm{k} 2 \mathrm{f}^{\wedge} \mathrm{k} 1 \mathrm{f}$.

2) Giving and asking goods or services: $(\mathbf{d a 1})^{\wedge}(\mathbf{a} 2)^{\wedge} \mathbf{a} 1^{\wedge}(\mathbf{a} 2 f)^{\wedge}(\mathbf{a} 1 f)$. From this formula, there are nine conversation structures that can be derived i.e. a1, $a 1^{\wedge} a 2 f, a 1^{\wedge} a 2 f^{\wedge} a 1 f, a 2^{\wedge} a 1, a 2^{\wedge} a 1 \wedge a 2, a 2^{\wedge} a 1^{\wedge} a 2 f^{\wedge} a 1 f$, da $1^{\wedge} \mathrm{a} 2 \wedge \mathrm{a} 1, \mathrm{da} 1^{\wedge} \mathrm{a} 2^{\wedge} \mathrm{a} 1^{\wedge} \mathrm{a} 2 \mathrm{f}$, and da $1^{\wedge} \mathrm{a} 2^{\wedge} \mathrm{a} 1^{\wedge} \mathrm{a} 2 \mathrm{f}^{\wedge} \mathrm{a} 1 \mathrm{f}$.

However, Martin (1992) adds that the development from that formula still possibly appears because the created structure is structure based on the usual conversation in society and social context is one of causes why the structure is developed. Martin's (1992) statement is supported by research result in Karonese conversation happened in Karonese funeral (Ginting, 2010).

\section{Research Method}

This research is descriptive qualitative by using ethnomethodology approach. Related to Garfinkel's (1967) language research in Denzin and Lincoln (1994, p. 264), it is explained that linguistic ethnomethodology is divided into two parts i.e. indexicality and reflexivity. Indexicality relates to how people express themselves through language and can be understood by other participants contextually. Meanwhile, reflexivity is the way of people in describing, analyzing, and criticizing things in social contexts in which all are interdependent. This research is descriptive because it fulfills the characters of descriptive method such as centralizing in problem solving existing nowadays and actual problem. The data were collected, arranged, explained, and analyzed (Surakhmad, 1982). These research data are the speeches in Karonese conversation in funeral collected by observing and recording the conversation there (observer was involved). The instruments used in collecting data were (1) video recorder used to collect accurate data, (2) Question sheet for interview to know the relationship of every speaker in that activity, (3) Participant observation sheet used by researcher to take note on what was happening that possibly could not be recorded.

The data were analyzed by the following steps: (1) Editing the recorded data by deleting the crying sound in giving speech; (2) Sorting the data out from sentences to clause and determining speech function, mode, and its exchange structure; (3) Coding the data; (4) Determining conversation structure paradigmatically and identifying structure variation happened based in conversation structure explained in theory; and (5) Making and verifying the conclusion.

\subsection{System of Karonese Conversation in Funeral}

As explained before, generally speaker makes choices based on conversation network. However, in Karonese language, system of the conversation network is not applied in Karonese ethnic; the relationship between addresser and addressee will influence on the choices they make in conversation (Ginting, 2010). Moreover, in funeral tradition of Karonese ethnic, interaction happens between the living person and the dead one in which the speaker projecting him/herself as the dead person. Therefore, different system of conversation network is formed which is different from common system of conversation network (Ginting, 2010).

In funeral, besides presenting his/her experiences, the speaker also can exchange them. The exchange of experiences is done not only to the present audience but also to the dead person. The choice made by speaker both in presenting experiences and exchanging experiences is giving and asking information and giving and asking services.

Presenting and exchanging experiences are done by speaker directly (contact as the second element of event) and in unusual context of situation which is funeral (context as the third element of event). The speaker in orientation as second factor of conversation system in unusual context of situation can make choices i.e. starting or responding. Starting and responding moves are done by speaker him/herself because speaker may protect $\mathrm{him} / \mathrm{h}$ rself as the dead person in responding thing.

Therefore, the speaker can respond/exchange experience in context of funeral situation, thus, in this conversation system, there is interaction between speaker and the dead person (as the third factor of conversation system). Interaction happened in this context is because the speaker projects him/herself as the dead person. 


\subsection{Structure of Karonese Conversation in the Funeral}

Based on the data analysis done, there are twenty-six conversational structures in funeral, nine structures of all, which are different, twelve structure developments, and same five structures proposed by Martin (1992). Table 1 shows all the structures.

Table 1. Structure of Karonese conversation in the funeral

\begin{tabular}{|c|c|c|}
\hline No. & Structure of Conversation & Explanation \\
\hline 1. & $\mathrm{k} 1 \bullet \bullet \bullet \bullet$ & Development \\
\hline 2. & $\mathrm{k} 1 \bullet$ & Development \\
\hline 3. & $\mathrm{k} 1 \bullet$ & Development \\
\hline 4. & $\mathrm{k} 2 \cdots \cdots$ & Development \\
\hline 5. & $k 2 \cdots$ & Development \\
\hline 6. & $\mathrm{k} 2 \bullet \bullet$ & Development \\
\hline 7. & a2 •..• & Development \\
\hline 8. & $a 2 \cdots$ & Development \\
\hline 9. & $\mathrm{a} 2 \bullet \bullet$ & Development \\
\hline 10. & $\mathrm{k} 2^{\wedge} \mathrm{NV}$ & Development \\
\hline 11 & $\mathrm{a} 1(\mathrm{a} 2)$ & Finding \\
\hline 12. & a2 •..• & Finding \\
\hline 13. & $\mathrm{k} 1 \bullet$. & Finding \\
\hline 14. & $\mathrm{k} 1 \wedge \mathrm{a} 2 \cdots \cdots \wedge \mathrm{k} 2(\mathrm{k} 1)$ & Finding \\
\hline 15 & $\mathrm{a} 2^{\wedge} \mathrm{a} 1(\mathrm{k} 1)^{\wedge} \mathrm{k} 2 \mathrm{f}$ & Finding \\
\hline 16. & $\mathrm{a} 2^{\wedge} \mathrm{a} 1(\mathrm{k} 2)$ & Finding \\
\hline 17. & $\mathrm{k} 1 \cdots$ & Finding \\
\hline 18. & $\mathrm{a} 2^{\wedge} \mathrm{NV}$ & Finding \\
\hline 19 & $\mathrm{k} 2^{\wedge} \mathrm{k} 1(\mathrm{k} 2)^{\wedge} \mathrm{k} 2 \mathrm{f}$ & Finding \\
\hline 20 & $\mathrm{k} 1^{\wedge} \mathrm{k} 2^{\wedge} \mathrm{k} 1 \mathrm{f}^{\wedge} \mathrm{k} 2 \mathrm{f}$ & Development \\
\hline 21 & $\mathrm{k} 1 \bullet^{\cdots} \wedge^{\mathrm{k} 2}$ & Development \\
\hline 22 & $\mathrm{k} 1$ & Similar \\
\hline 23 & $\mathrm{k} 2$ & Similar \\
\hline 24 & $\mathrm{a} 2$ & Similar \\
\hline 25 & a1 & Similar \\
\hline
\end{tabular}

Notes:

...*Following a structure, which means that structure happened more than four times of same speaker.

..-Following a structure, which means that structure happened more than three times of same speaker.

•-Following a structure, which means that structure happened more than four times of same speaker.

-Following a structure, which means that structure happened more than four times of same speaker.

( ): Move happens and its meaning relates or does not relate to what is discussed.

$(\mathrm{a} / \mathrm{k})$ : Structure has not been realized by ' $a$ ' or' $\mathrm{k}$ ' or others.

Speaker projects him/herself as the dead person.

\section{Discussion}

Based on the data analysis on both system and structure of conversation, it is found that factors determining the 
system and the structure of conversation in funeral are contexts of situation. The intended context of situation is context of funeral situation. In context of funeral situation, there is a culture that approves the speakers to exchange his/her experiences with the dead person by projection him/herself as the dead one. Therefore, the unusual conversation structure was created like in Table 1. Conversation structure 1-10 and 20-21 are categorized as developed structure because the structure was developed from conversation structure proposed by Martin (1992); for example, structure K1•• is developed structure of K1 which gave information and dots mean that speaker gave information four times, and so are $\mathrm{k} 1 \bullet \bullet \bullet$ and $\mathrm{k} 1 \cdots \bullet$. For structure categorized as finding like conversation structure, no. 1-19 is totally different structures with conversation structure proposed by Martin. Structures 1-19 is also called as unusual structure because usually such conversation or interaction between the alive person and the dead one never happened except in conversation happened in Karonese funeral; in this case, move is signed by leaning line $(/)$. For move followed by other moves in bracket such as a $2^{\wedge} \mathrm{a} 1(\mathrm{k} 2)$, this structure means that the speaker asked goods and services and was responded by asking information. It is not supposed to do so. When the speaker asks goods or services (a2), it is responded by giving goods and services so that structure $\mathrm{a} 2 \wedge \mathrm{a} 1$ was created.

\section{Conclusion}

Based on the data analysis, it can be concluded that there is an interaction between the alive person and the dead one in Karonese culture. The interaction happens in funeral because the speaker gives speech-projecting $\mathrm{him} /$ herself as the dead person. Therefore, in Karonese funeral, there are different/unusual conversation structure, developed structure, and usual conversation structure.

\section{References}

Berry, M. (1981). Systemic linguistics and discourse analysis: A multilayered approach to exchange structure. In M. Coulthard, \& M. Montgomery (Eds.), Studies in discourse analysis. London: Routledge \& Kegan Paul.

Bloor, T., \& Bloor, M. (2004). The Functional Analysis of English: A Hallidayan Approach. London: Arnold.

Chapelle, C. A. (1998). Some notes on Systemic-Functional Linguistics. Retrieved October 26, 2006, from http//www.public.iastate.edu/ carolc/LING511/sfl.html

Christie, F. (2002). Classroom Discourse Analysis: A Functional Perspective. London: Continuum.

Denzin, N. K., \& Lincoln, Y. S. (1994). Handbook of Qualitative Research. California: SAGE.

Eggins, S. (1994). An Introduction to Systemic Functional Linguistics. London: United Kingdom.

Eggins, S., \& Slade, D. (1997). Analysis of Casual Conversation. London: Wellington House.

Fries, P. H., \& Gregory, M. (Eds.). (n. d.). Discourse in Society: Systemic Functional Perfectives. New Jersey: Ablex.

Gazden, C. V. J., John, V. P., \& Hymes, D. (Eds.). (1972). Function of Language in the Classroom. New York: Teachers College Press.

Gerot, L., \& Dan Wignell, P. (1994). Making Sense of Functional Grammar. Australia: Gerd Stabler.

Ginting, M. U. (2008). Adat Karo Sirulo. Medan: Prima.

Ginting, S. A. (2008a). Peran Hubungan Kekerabatan dalam Pembentukan Struktur Percakapan dalam Puspitorini, dkk. Kajian Wacana dalam Konteks Multikultural dan Multidisiplin, 145. Jakarta: Fakultas Ilmu Budaya (FIB) UI.

Ginting, S. A. (2008b). Sistem Tutur Sapaan dalam Bahasa Karo dalam Fungsi Antarpersona dalam Prosiding Jilid 2. Seminar Antar Bangsa: Dialek-dialek Austronesia di Nusantara, III, 439.

Ginting, S. A. (2010a). Ketidaklangsungan Percakapan Merupakan Kesantunan Bagi Penutur Bahasa Karo dalam Widaya, Dwi. Proceedings. Seminar International: Language, Literature, and Culture in SouthEast Asia. Hal.

Ginting, S. A. (2010b). Metafora Bahasa Karo dalam Artawa, I Ketut. Persfektif Bahasa-bahasa Austronesia dan Non Austronesia, 265. Bali: Udaya University Press.

Ginting, S. A. (2010c). Sistem dan Struktur Percakapan dalam Bahasa Karo. Medan: Universitas Sumatera Utara. Desertasi.

Halliday, M. A. K. (1975). 'Language as social semiotic: towards a general sociolinguistic theory dalam A. Makkai dan V. B. Makkai. The First LACUS Forum 1974. Colombia, SC: Hornbeam (Reprented in Halliday 1987).

Halliday, M. A. K. (1978). Langugae as a social Semiotic. London: Edward Arnold.

Halliday, M. A. K. (1985a). An Introduction to Functional Grammar. London: Edward Arnold. 
Halliday, M. A. K. (1985b). Context and Text: Aspects of Language in Social Semiotic Perfectives. Geelong: Deakin University Press.

Halliday, M. A. K. (2002). Linguistics Studies of Text and Discourse. Great Britain: MPG Books Bodmin Cormwall.

Hymes, D. H. (1962/1974). 'The ethnography of Speaking'. In B. G. Blount (Ed.), Language Culture and Society (pp. 189-233). Cambridge: Winthrop.

Hymes, D. H. (1964/1972). 'Towards ethnographies of communication: the analysis of communicative events'. Language and Social Context (pp. 21-24).

Hymes, D. H. (1971/1972). On communicative competence. In J. B. Pride, \& J. Holmes (Eds.), Sociolinguistics (pp. 269-293). Harmondsworth: Pinguin.

Johnstone, B. (2008). Discourse Analysis (2nd ed.). Australia: Blackwell.

Lemke, J. (1985). 'Ideology, interaction, and second language acquisition' in Benson and Graves. Systemic Persfectives on Discourse (Vol. 2, pp. 275-294). Noorwood, New Jersey: Ablex.

Martin, J. R. (1984). Functional components in grammar: A review of deployable recognition criteria. Nottingham Linguistic Sircular, 13, 35-70.

Martin, J. R. (1992). English Text. Philladelphia: John Benjamins. http://dx.doi.org/10.1075/z.59

Martin, J. R. (2008). Genre Relation: Mapping Culture. London: Equinox.

Martin, J. R., \& Rose, D. (2002). Working with Discourse: Meaning Beyond the Clause. London, New York: Continuum.

Martin, J. R., \& White, P. R. R. (2006). The Language of Evaluation. New York: Palgrave.

Paltridge, B. (2006). Discourse Analysis. London, New York: Continuum.

Poynton, C. (1985). Language and Gender: making the difference. Victoria: Deakin University.

Prinst, D. (2004.) Adat Karo. Medan: Bina Media Perintis.

Saragih, A. (2005). Bahasa dalam Konteks Sosial: Pendekatan Linguistik Fungsional Sistemik terhadap Tata Bahasa dan Wacana. Medan: Universitas Negeri Medan.

Saragih, A. (2006). Discourse Analysis: A Systemic Functional Approach. Medan: Universitas Negeri Medan.

Saragih, A. (2006). Makna Antarpersona dalam Bahasa Simalungun. Prosiding Jilid, 2. Seminar Antar Bangsa: Dialek-dialek Austronesia di Nusantara, III, 113.

Saragih, A. (2009). Semiotik Bahasa: Tanda, Penanda dan Petanda. Medan: Pascasarjana Universitas Negeri Medan.

Schegollf, E. A. (1968/1972). Sequencing in conversational opening. In J. Laver, \& S. Dan Hutcheson (Eds.), Communication in Face to Face Interaction (pp. 233-264). Harmondsworth: Penguin. http://dx.doi.org/10. 1525/aa.1968.70.6.02a00030

Schegollf, E. A., \& dan Sacks, H. (1973-1974). 'Opening up closing. In R. Turner (Ed.), Ethnomethodology (pp. 374-405). Harmondsworth: Penguin.

Silverman, D. (2001). Ed kedua. Interpreting Qualitatif Data: Methods for Analysing Talk, Text and Interaction. London: SAGE

Spradley, J. P. (1980). Participant Observation. New York: Holt, Rinehart and Winston.

Thomas et al. (1999). Language Society and Power. London: Routledge. http://dx.doi.org/10.4324/ 9780203426968

Thomas, J. A. (1985). The Language of Power: towards a Dynamic Pragmatic. Journal of Pragmatics, 9 , 765-783. North Holland. http://dx.doi.org/10.1016/0378-2166(85)90003-7

Thompson, G. (1996). Introducing Functional Grammar. London: Edward Arnold.

Thompson, G. (n. d.). What is Systemic-Functional Linguistics? Retrieved October 26, 2009, from http://www.wagsoft.com/Systemics

\section{Copyrights}

Copyright for this article is retained by the author(s), with first publication rights granted to the journal.

This is an open-access article distributed under the terms and conditions of the Creative Commons Attribution license (http://creativecommons.org/licenses/by/3.0/). 